\title{
The business financial inclusion benefits from an Islamic point of view: a qualitative inquiry
}

The business financial inclusion benefits

\author{
Umar Habibu Umar \\ Department of Accounting, \\ Yusuf Maitama Sule (Formerly Northwest) University Kano, Kano, Nigeria
}

\begin{abstract}
Purpose - This study explores the benefits of business financial inclusion from the Islamic perspective in Nigeria by selecting Kano state as a case study.

Design/methodology/approach - Primary data were generated through semi-structured interviews with experts who comprised professional accountants/consultants and experienced traders. Thematic analysis was applied to examine the data collected. In addition, observations were made in some selected stores and shops to complement the interview results.

Findings - The study finds that the benefits of business financial inclusion include recordkeeping improvement, reduction of the risks of bad debts, reduction of the risks associated with cash, enhancing business zakāh for poverty alleviation, sales improvement and business growth, getting supports from government and other development organizations and the provision of employment opportunities.

Research limitations/implications - This study is purely qualitative, and, as such, it has some limitations in terms of generalization.

Practical implications - The practical implication of this study is that the use of electronic payment methods, especially point of sales, enhances the business financial inclusion, which consequently maximizes their wealth and contributes to the reduction of poverty to the barest minimum in the society.

Social implications - The social implication of the findings is that businesses that are financially included are in a better position to discharge religious, philanthropic and other benevolent activities, such as $z a k \bar{a} h$, qard hasan, waqf and sadaqah, for the welfare of the ummah.

Originality/value - The study points out the benefits of financial inclusion not only to businesses but also to other members of the society at large.
\end{abstract}

Keywords Business, Financial inclusion, Recordkeeping/bookkeeping, Zakāh, Employment, Poverty alleviation

Paper type Research paper

\section{Introduction}

Financial inclusion is believed to be a central objective of many developing economies (Sharma and Kukreja, 2013). Recently, enhancing access to financial services enjoys special consideration on the agenda of many economies in the world (Brekke, 2018; Naceur et al., 2015; Seman, 2016). It has become a universal activity and concern for policymakers and regulators for developing the financial sector in order to achieve a maintainable long-term economic objective (Zulkhibri, 2016). According to the World Bank's 2014 Global Financial Development Report (GFDR), more than 50 nations have formally established their targets for enhancement of financial inclusion (Naceur et al., 2015).

\section{JEL Classification - E24, E58, M40 I30. KAUJIE Classification - H52, J42, E23}

(C) Umar Habibu Umar. Published in Islamic Economic Studies. Published by Emerald Publishing Limited. This article is published under the Creative Commons Attribution (CC BY 4.0) license. Anyone may reproduce, distribute, translate and create derivative works of this article (for both commercial and non-commercial purposes), subject to full attribution to the original publication and authors. The full terms of this license may be seen at http://creativecommons.org/licences/by/4.0/legalcode

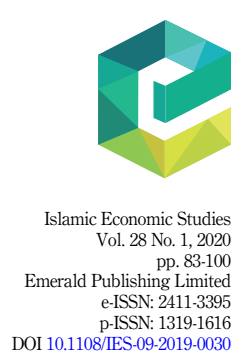


IES

28,1

Nigeria is not an exception in struggling for achieving a higher financial inclusion rate. Several measures, such as agent banking, tiered Know-Your-Customer (KYC) requirements, financial literacy, consumer protection, linkage banking, the implementation of the Micro, Small and Medium Enterprises Development Fund (MSMEDF) and credit enhancement programs, among others, have been put in place by the Central Bank of Nigeria $(\mathrm{CBN})$ in collaboration with other organizations with a view to attaining a financial inclusion rate of $80 \%$ by the year 2020 (Zauro et al., 2017a). A survey conducted in 2018 showed that over $60 \%$ of the Nigerian adult population has become financially included (Enhancing Financial Innovation and Access (EFInA), 2018). Perhaps, this motivated the governor of the CBN and chairman of the National Financial Inclusion Steering Committee to set further higher the next target of achieving a 95\% financial inclusion rate by the year 2024 (CBN, 2019).

Meanwhile, Islamic banking serves as an instrument for achieving financial inclusion (Naceur et al., 2015). In 2011, the CBN approved the establishment of an Islamic bank (IB) with a view to providing alternatives to conventional finance that are Sharíah-compliant for economic growth and development (Zauro et al., 2017b). Currently, another full-fledged IB, named Taj Bank Limited, has emerged and commenced operation in Nigeria on December 2, 2019. Also, a Nigerian conventional bank that earlier had an Islamic window is making all the necessary preparations for conversion into a fully Shariah-compliant bank. These show the potential contributions of the Nigerian Islamic banking industry in enabling Nigerians to have access to Islamic financial services.

Many empirical studies were conducted on the link between Islamic finance and financial inclusion defined with different objectives in different countries, such as Beg and Mullick (2016), Brekke (2018); Demirguc-Kunt et al. (2014); Er and Mutlu (2017); Naceur et al. (2015); Zulkhibri (2016); Ali (2015) and Umar et al. (2019). These studies failed to clearly point out the advantages and benefits of business financial inclusion.

Given this background, the objective of the present study is to explore the benefits of accessing business financial services from an Islamic point of view in Nigeria by selecting Kano state as a case study. Kano was selected as a case study for four reasons. First, it is the most populated state in Nigeria. Second, historically, it is the Nigerian center of commerce. Third, it is not only dominated by Muslims but also has the highest number of Muslims among the Nigerian states. Fourth, after releasing the revised Nigerian Financial Inclusion Strategy in January 2019, the CBN organized a stakeholders' forum in each of the six zones of Nigeria to educate Nigerians on the provisions of the strategy and fashion out implementation activities at the grassroots level. Kano was selected in the North-West Geo-Political Zone (CBN, 2019). Hence, the forum is expected to improve the financial inclusion rate in the state.

The remainder of the paper is divided into four sections: literature review, methodology, research findings and conclusion.

\section{Literature review}

\subsection{A brief history of the case study}

"Centre of Commerce" is the slogan of Kano, which is among the 36 states of the country. McDonell (1964) describes it as the largest city in Western Sudan, and for many centuries, commercial relations have existed between the state and North African and European regions [1]. Trading activities and other contacts between the community and North African countries were considerably developed, and at the same time, Songhai Empire came to the west of Hausa land (Kano is a part of the area), which brought about development in the social, economic and political activities in the community (Dan-Asabe, 1987). In the same way, historically, since the 7th century, different types of markets have existed in Kano, some of which attracted people in neighboring countries, such as Benin, Burkina Faso, Cameroun, Central Africa Republic, Chad, Ghana, Niger and Togo (Ibrahim, 2015). 
Further, Kano is the most populated state in Nigeria, with a population of 10 million during the 1991 census (Muktar, 2013). But now the population is estimated to be around 15 million, and the Muslim population in the state is estimated to be about $95 \%$ or $8.06 \%$ of the estimated Nigerian population of 186 million people in 2016 (Mustafa et al., 2018). Therefore, being an Islamic state, its affairs are guided by the Shariah. Besides, the state is blessed with an uncountable number of successful entrepreneurs, who engage in different businesses located in the state, other states in the country and abroad. Even the richest person in Africa, Alhaji Aliko Dangote, hails from the same state. His maternal family members are very rich and popularly known as "Alasawa."

\subsection{The concept of financial inclusion}

Financial inclusion has an all-encompassing definition. It has many dimensions, which depend on the stages of development and its degree varies among different countries (Sharma and Kukreja, 2013). Seman (2016) defined it as a means of delivering financial services at a cost that can be afforded by the less-privileged, weaker and low-income earners of the society, both individual households and small and medium enterprises (SMEs). It could be seen as the provision of financial services at affordable costs to the underprivileged and low-income earners of the society (Kelekar, 2009; Sharma and Kukreja, 2013). Similarly, Umar et al. (2019) described financial inclusion as a situation in which individual and corporate entities get easy access to formal financial services like credit, formal savings, formal payments, insurance and pension-saving products at affordable costs.

In Islamic finance, financial inclusion entails access to finance from two points: promotion of risk-sharing contracts through the provision of feasible and non-interest finance and the provision of income redistributions instruments for poverty alleviation (Mohieldin, et al., 2012; Mirakhor and Iqbal, 2012; Zulkhibri, 2016). Mushārakah is an example of a Sharíahcompliant and risk-sharing contract, which is commonly practiced by IBs, though it could be formed by individuals or non-IBs (Umar, 2019a). Any form of mushärakah (whether with an Islamic or a non-IB) needs to be sustained to provide employment opportunities, redistribute incomes, maximize business $z a k \bar{a} h$, discharge waqf activities and so forth, to alleviate poverty and maximize the welfare of the ummah as well as achieve economic growth and development at large. Besides, to encourage musharakah business in Islamic society, Umar and Kurawa (2019) recommend the admission of heirs into the inherited business in order to allow the business to remain a going concern. Further, $z a k \bar{a} h$ and waqf are common examples of the instruments for the redistribution of income in society toward poverty alleviation in Islamic society. Umar (2019b) and Umar et al. (2020) support the integration of waqf into a going concern business for the welfare of heirs and non-heirs and the sustainability of the business. Consequently, as long as the business exists, business zakāh would be paid for eradicating poverty. However, Islamic microfinance and micro-insurance are found to have a more significant contribution in improving the financial inclusion rate than Shariahcomplaint contracts (Beg and Mullick, 2016). This is because Islamic microfinance provides funds to the poor members of the society in line with the Shari ${ }^{c} a h$, which enables them to become self-dependent (Ali, 2015). The poor and the needy are the majority in developing countries.

Further, Shaikh et al. (2017) suggest three ways of enhancing Islamic financial inclusion through Islamic banking: the application of information technology to accommodate those that are excluded because of distance barrier, the use of equity-based modes of financing to support those that have no collateral security and giving entrepreneurial capital and other sources of income and paying special attention to Islamic microfinance for supporting the poor members of the society. In Nigeria, since the majority of people are poor, Islamic microfinance, if judiciously applied, would significantly contribute to the achievement of Nigeria's target financial inclusion rate, particularly by the year 2024 .
The business financial inclusion benefits 
IES

28,1

86

\subsection{Empirical studies}

Many empirical studies on financial inclusion were carried out in both Muslim and non-Muslim countries. Some studies are regional, while others are limited to one country. Some of the regional studies include Andrianaivo and Kpodar (2012); Demirguc-Kunt et al. (2014); Naceur et al. (2015); Ocampos (2015); Zulkhibri (2016) and so forth. Andrianaivo and Kpodar (2012) assessed the relationship between mobile phone and economic growth in some selected African nations between 1998 and 2007. They found that mobile phones have significantly contributed to economic growth in the countries, part of which emerged as a result of financial inclusion. Demirguc-Kunt et al. (2014) utilized novel data with the objective of exploring access to financial services by drawing on a sample of 65,000 Muslim adults across 64 countries. The study discovered that Muslims are notably less likely than non-Muslims to formally open bank accounts or deposit their funds at conventional banks when individual- and country-level characteristics are controlled for. Naceur et al. (2015) investigated the association between Islamic banking and financial inclusion in member countries of the Organization of Islamic Cooperation (OIC). The result revealed that access to financial services has been improved physically but at a slow rate, and a tentative and an insignificant positive link to household credit and firms for financing investment is found. Moreover, this study made the following vital recommendations with the view to improving the contribution of IBs toward financial inclusion: i) IBs should establish a section for the SMEs, and their staff need to be trained more on contracts that are fully Sharíah-compliant, ii) all the potentials of Islamic microfinance should be utilized, and Islamic equity funds for the SMEs should be established and iii) improvement in financial infrastructure and the quality of credit information and encouraging competition in the banking industry, among others, could increase financial inclusion of the public.

Furthermore, Ocampos (2015) utilized data generated from the IMF and the World Bank databases on financial inclusion indicators with the view to assessing the contribution of IBs to financial inclusion. It was discovered that the IBs have insignificantly influenced financial inclusion. Besides, the results showed that the citizens of the members of the OIC do not have access to financial services, and, as such, they make less use of them if compared to the citizens of non-member countries. Ali (2015) sought to find out whether Islamic microfinance could eradicate poverty in Islamic countries. The study established that unlike conventional microfinance, Islamic microfinance offers not only financial inclusion but also social inclusion (through the provision of sadaqah, waqf and zakāh to the poor and needy members of the society) to satisfy the basic needs of the society before credit is granted. Social inclusion here serves as a motivator to the underprivileged members of the Islamic society. Therefore, Islamic microfinance plays a significant role in eradicating poverty. Zulkhibri (2016) applied a qualitative method to ascertain the relationship between financial inclusion and the Islamic financial services industry in the Muslim world. The study revealed that a lot of individuals and businesses are yet to be financially included, and cost, distance, documentation, trust and religious adherence are found to be among the major factors hindering the achievement of financial inclusion. Specifically, more than 40 million Muslims have no formal access to financial services solely for religious purposes.

Other studies on Islamic financial inclusion, which are limited to one country, include Er and Mutlu (2017); Brekke (2018) and so forth. Er and Mutlu (2017) undertook their study to find the level of the financial literacy of financial inclusion in Turkey. The study found the general index of Islamic financial literacy to be $58 \%$. Brekke (2018) collected data in Norway between 2015 and 2016 and discovered that the banks in the country did not offer products that were in line with the Shariah, which is considered to be a principal factor hindering the integration of Muslims in the country. More so, through interviews and focus group discussions, he established that Muslims in Norway agreed that, over the years, there was a high demand for Islamic financial products as a result of the increase in the awareness of Islamic economics. 
Further, some studies were carried out in Nigeria on financial inclusion. For example, Achor and Robert (2013) surveyed the opinions of businessmen, university students and civil servants about Nigeria's cashless policy. The study revealed the acceptance of the policy by the public since it tends to minimize cash robbery and corrupt practices as well as other related offenses, but it exposed them to cybercrime; also, there is a high rate of illiteracy. Similarly, Okoye and Ezejiofor (2013) administered questionnaires to assess the development of the cashless economy policy in Nigeria. The study disclosed that the majority of the respondents are aware of the policy, and they believe that it could be used to combat corruption in Nigeria as well as eliminate the risk of taking cash from one place to another. But cybercrimes and illiteracy have been discovered as the factors hindering the achievement of the cashless policy. Oyewole et al. (2013) investigated the impact of the various methods of electronic payments on the growth of the Nigerian economy between 2005 and 2012. The study established that automated teller machines (ATMs) have positively contributed to the economic growth of Nigeria, whereas online payment, POS terminals, mobile payments and checks have negative relationships with the growth.

Another study undertaken by Bayero (2015) established that awareness, consumer/user value proposition and infrastructure have significant relationships with financial inclusion, whereas the business model of financial services providers has an insignificant relationship with financial inclusion in Nigeria. Zauro et al. (2017a) administered questionnaires in order to find the effect of attitude, religiosity and ethnicity on financial inclusion in Nigeria. The study found that these variables (impact attitude, religiosity and ethnicity) have significant relationships with financial inclusion. Therefore, special consideration should be given to them in order to enhance financial inclusion. More recently, Umar et al. (2019) explored whether religion (interest) in Nigeria hinders the achievement of Nigeria's financial inclusion target rate of $80 \%$ by the year 2020 . The data for the study were generated through semistructured interviews and documentary evidence. It established that almost all the programs of the Nigerian Central Bank that enhance financial inclusion are not Shariah-compliant, as they involve interest. However, the majority of Muslims are still participating in these programs. Therefore, interest is not a factor hindering Nigeria's financial inclusion target set to be achieved by the year 2020. But they recommend for the provision of Islamic windows before Muslims begin to shun these programs because many influential Muslim preachers are now preaching against interest.

\section{Methodology}

This study utilized a semi-structured interview method that was adapted from previous studies (Eldabi et al., 2002; Horton et al., 2004; Nor and Hashim, 2015; Thaker, 2018). It is a qualitative method that emphasizes more on understanding and describing a process instead of behavioral outcomes (Bakar and Yusof, 2016; Nor and Hashim, 2015). Moreover, it enables the researcher to seek further in-depth explanations on some responses with the view to resolving apparent contradictions (Horton et al., 2004). Hence, this approach is considered to be a way of finding social reality from the subject, not from the observer (Eldabi et al., 2002).

Professional accountants (working in audit and consultancy services firms) and experienced traders were interviewed in order to achieve the objective of the study. Purposive sampling technique was applied to select the respondents. It is the most common sampling technique used for pre-selecting respondents based on a particular research question (Thaker, 2018). Nowadays, it is widely used as a method of sampling in qualitative research (Gentles et al., 2015). This is applied to ensure that experienced and qualified respondents were selected to provide answers to research questions. In the case of sample size, six respondents were selected based on the principle of data saturation as used by Thaker (2018). The purpose of data saturation is to avoid oversampling of interviewees which
The business financial inclusion benefits 
IES

28,1

88

tends to make the data become redundant (Marshall et al., 2013). Thus, the sample of the six participants was assumed to be enough. Similarly, unlike quantitative research where a large sample size is preferred, in qualitative research, a small sample size is recommended with the view to acquiring information that could enable one to understand the complexity, depth, variation or context surrounding a phenomenon (Gentles et al., 2015).

The data collected through the interviews with the participants were transcribed into field notes and analyzed by the application of thematic analysis, as applied by Thaker (2018). Table 1 presents the profile of the respondents:

Table 1 shows that there are six respondents. The first three (A1-A3) are professional accountants/consultants, who have been rendering accounting/auditing and other consultancy services to businesses for many years. The next two (A4 and A5) are traders with accounting and finance background. The last one (A6) worked as an accountant for one of the stores that are financially included in the state.

In spite of financial inclusion as a contemporary and topical issue, prior studies have not yet clearly pointed out the comprehensive benefits of business financial inclusion. However, the literature on cashless policy and financial inclusion was reviewed to explore the expected benefits of business financial inclusion, which would serve as a basis for developing the categorical themes of the interviews. According to the CBN (n.d.), the anticipated benefits of the cashless economy would, among others, include faster access to capital, reduction in cashrelated crimes, increased convenience, access to adequate credit facilities (by business), faster access to capital (by businesses), reduced revenue leakage and cash handling costs, among others. Similarly, Achor and Robert (2013) established that the cashless economy has the potential to reduce cash-related robberies, corruption and other fraudulent practices. Hence, eight expected benefits of business financial inclusion could be pointed out. It is worth noting that some benefits would serve as the drivers of others.

First, when a business is financially included, most of its receipts and payments will be done through banks. This implies that bank statements will provide substantial information concerning receipts and payments for the preparation of the comprehensive financial statements of businesses. A bank statement is one of the essential source documents needed to prepare the financial statements of a business (Umar, 2019a). Second, effective financial inclusion provides various alternative means of electronic payments, such as online payment, credit transfer, debit cards and POS, which enable customers to make payment when they have no cash in hand. Consequently, this would contribute to the reduction of bad debts. Third, financial inclusion is likely to contribute to minimizing the risks associated with carrying cash. Fourth, if a business has access to adequate credit facilities, it has its revenue leakage fraudulent activities reduced. Thus, it has the potential to grow and increase its revenue. Fifth, when a business grows and has its revenue increased as well, there is a tendency to pay more $z a k \bar{a} h$. Sixth, as the business grows, it would provide more employment opportunities. Hence, it is believed that successful financial inclusion would increase employment (Dixit and Ghosh, 2013; Ali, 2015; Er and Mutlu, 2017).

\begin{tabular}{llr}
\hline No & Profession / Occupation & Code \\
\hline 1. & Professional accountant/Consultant & A1 \\
2. & Professional accountant/Consultant & A2 \\
3. & Professional accountant/Consultant & A3 \\
4. & Trader & A4 \\
5. & Trader & A6 \\
6. & Accountant & A
\end{tabular}


Seventh, for about a decade, the Nigerian government has adopted the cashless economy, which greatly contributes to the increase in the financial inclusion rate. This is because many Nigerians have bank accounts through which they make and receive payments. It has now become a rule that for any individual or organization to benefit from the Nigerian government and NGOs (both local and international), they must operate bank accounts through which payments and receipts are done. Eighth, it is worth noting that businesses that grow (size) and earn higher profits are likely to increase and disclose more CSR activities in their annual reports and accounts. These findings are based on the survey and content analysis of 76 empirical studies conducted in both developed and developing countries (Ali et al., 2017).

Briefly, eight benefits of business financial inclusion could be pointed out. All benefits are not independent - some are the drivers of the others. For example, when a business grows and its revenue increased, it is likely to pay more $z a k \bar{a} h$ for poverty alleviation. It is also expected to employ more workers. Table 2 shows the eight categorical themes based on the issue discussed above.

Table 2 shows the eight categorical themes and the interview questions about the benefits of business financial inclusion. In line with Thaker (2018), the responses were transcribed into field notes. Besides, observations were made in various stores and shops that are financially included, such as Jifatu Stores, Sahad Stores and Sammanin Fatihu Stores, in order to support the interview results.

\section{Research findings}

It has been observed that the most common and popular means of making electronic payments in the stores and the shops is the point of sales (POS) terminal. The POS has now become a powerful instrument that significantly enhances the financial inclusion of business. Also, all the sample stores and the shops have barcode machines, which are used to record all the inventories purchased and sold. The machines print invoices for the purchases made by customers.

The results of the interviews based on the eight major themes and the observations are presented below.
The business financial inclusion benefits

89

\begin{tabular}{|c|c|c|}
\hline No & Categorical themes & Interview questions \\
\hline 1. & Recordkeeping improvement & $\begin{array}{l}\text { Can financial inclusion improve the recordkeeping of the } \\
\text { business? }\end{array}$ \\
\hline 2. & Reduction of the risks of bad debts & $\begin{array}{l}\text { Do you think financial inclusion can reduce, if not eliminate, } \\
\text { the business exposure to bad debts? }\end{array}$ \\
\hline 3. & $\begin{array}{l}\text { Reduction of the risks associated with } \\
\text { cash }\end{array}$ & How can financial inclusion minimize cash exposure to risks? \\
\hline 4. & $\begin{array}{l}\text { Enhancing business } z a k \bar{a} h \text { for poverty } \\
\text { alleviation }\end{array}$ & $\begin{array}{l}\text { Can business } z a k \bar{a} h \text { be enhanced for poverty alleviation } \\
\text { through financial inclusion? }\end{array}$ \\
\hline 5. & $\begin{array}{l}\text { Sales improvement and business } \\
\text { growth }\end{array}$ & $\begin{array}{l}\text { Do you believe that financial inclusion leads to sales } \\
\text { improvement and business growth? }\end{array}$ \\
\hline 6. & $\begin{array}{l}\text { Support from government and other } \\
\text { development organizations }\end{array}$ & $\begin{array}{l}\text { Can financial inclusion enable businesses to have access to } \\
\text { the support of government and other development } \\
\text { organizations? }\end{array}$ \\
\hline 7. & Provision of employment opportunities & $\begin{array}{l}\text { Do you agree that financial inclusion can improve } \\
\text { employment opportunities in Nigeria? }\end{array}$ \\
\hline 8. & Corporate social responsibility (CSR) & $\begin{array}{l}\text { Do you believe that financially included businesses are likely } \\
\text { to discharge more CSR than the others? }\end{array}$ \\
\hline
\end{tabular}


IES

28,1

\subsection{Recordkeeping improvement}

The records to keep comprise those of assets, liabilities (debts), incomes and expenses. Moreover, the proper recording of business transactions is one of the vital functions of Islamic accounting. The views of the respondents were sought on whether financial inclusion could enhance the recordkeeping of the business. All the respondents $(n=6)$ replied in the positive. The following are the responses with respect to the role of the financial inclusion on improving the recordkeeping of the business:

[...] businesses that use POS terminals and barcode machines could easily determine their total sales, total purchases, inventory balances [... ] on a real-time basis. (A1)

Financial inclusion improves the recordkeeping of the businesses by the use of POS and barcode machines [.. . ] in order to prevent fraudulent activities and ensure the reliability and the accuracy of the records. The attendants/cashiers/sales representatives should not be granted administrative access to the barcode machines and they should also be rotated regularly without notice. (A2)

Traders that are not financially included should keep single entry records, i.e. incomplete records $[\ldots]$ the use of POS could enhance the recordkeeping of the business since most of the receipts and payments of the business are going to be reflected in the bank statement. (A3)

[...] those that use POS and other cashless payment methods tend to keep complete records more than the others that do not. (A4)

Business financial inclusion could enhance its recordkeeping [...] the use of POS and barcode machines could enable businesses to develop the culture of recordkeeping. (A5)

Financial inclusion of the business boosts its financial records because substantial receipts and payments are made through bank [...] the business also uses barcode machines to capture sales, purchase of inventories [...]. It also enables the business to generate total sales, purchases and inventories balances any time the need arises. (A6)

The above responses show that financial inclusion would definitely lead to the enhancement of the recordkeeping of the business. Substantial transactions of the business involving receipts and payments could be captured in the bank statement. Hence, businesses that are serious about financial inclusion are likely to have more complete records than others. Similarly, based on the observations made in the visited shops and stores, some staff were found to have been primarily employed to take charge of recordkeeping and accounting functions. In addition, it has also been observed that all the purchases made by customers must be entered into the barcode machine with a view to printing invoices/receipts for them. Hence, the machine could be used to generate reports for purchases, sales and inventory balances at any time.

Moreover, the importance of the recordkeeping for planning, controlling and decisionmaking toward achieving the objectives of the business, especially profit and wealth maximization, is very profound. Recordkeeping provides the information needed for applying various management accounting techniques such as budgeting standard costing, marginal costing techniques (such as make or buy decision, the acceptance or rejection of a special order, allocation of scarce resources, etc.) and standard costing and variance analysis. in order to achieve the objectives of the organization efficiently and effectively. This is only possible if there are sufficient and accurate records of the business transactions.

Recordkeeping of the business has been emphasized in both the Noble Qur'an and the Sunnah of the Prophet Muhammad (SAW). Allah (SWT) decrees that contracting a debt for a fixed period between two parties should be written down (Al-Baqarah, 2:282). The importance of keeping records is also established by the Sunnah of the Prophet (SAW), as reported by Abdullahi Bin Umar, who said it was not allowed for a Muslim to spend two consecutive nights without having his will in written form with him (Sahih Bukhari, Vol. 4, Book 51, No. 1; and 
Sahih Muslim, Book 013, No. 3987). This hadith could provide a good lesson to traders to adopt the system that would enable them to keep records of their business transactions regularly.

\subsection{Reduction of the risks of bad debts}

Excessive credit sales lead to a high amount of bad debts, which tend to reduce the profit and the wealth of the business or even make it collapse. In financial reporting, the amount of bad debts is expensed, which consequently reduces the profit and the wealth of the business. Hence, the views of the respondents were sought on whether or not financial inclusion of business reduces or eliminates bad debts. They all $(n=6)$ viewed that the financial inclusion of the business could reduce business exposure to bad debts as a result of credit sales. They provide the following responses:

[...] sales are almost made based on cash and carry basis by financially included business and therefore bad debts are eliminated or minimized to the barest minimal. (A1)

[...] some of these traders make a few credit sales to trusted Allies/ customers in such a way that the other customers do not know [. . . . It reduces the incidents of bad debts because the credit sales are reduced to the barest minimal. (A2)

It minimizes the exposure of the business to the risks of bad debts since there are little or no credit sales to the customers [...]. (A3)

Businesses that are financially included are not exposed to the risks of bad debts because most of their sales are made based on cash and carry basis. (A4)

[... ] they are less likely to be exposed to the risks of bad debts because they mostly make credit sales to very few numbers of customers who are mostly government and corporate bodies. (A5)

Most of the sales are based on "cash and carry" (either to pay by using POS terminal or in cash) [...] the credit sales which are only made to the tested and trusted customers are very low and are mostly payable within few days (usually 3 days) [. . . ] as such the exposure of the businesses to the bad debts is very low. (A6)

The responses confirm that businesses that use POS terminals are not exposed to the risks of credit sales. Customers that want to purchase goods from them must either use POS terminals to make the payment or pay cash instantly. Similarly, throughout our stay in the shops and the stores during the observations, we could not see a single credit transaction made openly.

\subsection{Reduction of the risks associated with cash}

Cash is the most important asset of the business, which is exposed to various risks. Economically, there are three motives for holding cash: transaction, precautionary and speculative. It needs to be properly managed with the view to utilizing it in such a way as to maximize the wealth and the profit of the business. The interviewees were asked if business financial inclusion could reduce cash-related risks. The participants $(n=6)$ agreed that financial inclusion is a strong instrument for minimizing the risks associated with cash. The responses are as follows:

[...] incomplete cash balances could be avoided [...] there is also control over cash sales as it (business) always sets aside imprest (petty cash) with the view to avoiding spending directly from cash sales. (A1)

Financial inclusion of the business could assist in minimizing cash pilferages [...]. (A2)

[...] it enables the business to have control over the cash by preventing the staff from making fraudulent spending and pilferages [...]. (A3)

Financial inclusion could prevent the business against cash shortage, pilferages, etc. In fact, many cases have been established (some are still going on) whereby employees were found guilty of conniving with
The business financial inclusion benefits 
IES

28,1

92

armed robbers to snatch the cash kept in the office by force or even using deadly weapons [...] many employees and other innocent persons lost their lives during the operations/attacks. (A4)

Cash shortage and pilferages of daily sales could be reduced to the barest minimal [ . . ] during fire accidents in some market in the state such as Sabon Gari Market, Singa Market, Farm Centre Market [...] traders that are not financially included are the ones that suffer most because they mostly keep their cash in their offices [...] one culture of the financially included business is that at the end of every week (usually Friday) they pay their cash sales into their businesses accounts. (A5)

Financially included business is less likely to be exposed to the risks that are related to cash such as fire, pilferages [...] because at least $50 \%$ of the sales are received by using POSs and even the cash sales are banked within not more than 24 hours [. . . ] therefore cash pilferages is reduced to the barest minimal. (A6)

In addition to the above responses, many traders, especially the ones that travel to other states, are exposed to the danger of armed robbers along the way or even at the markets. In fact, some of them not only loss their monies but also their lives. This risk forced many Nigerian traders to open bank accounts with a view to making cashless payments for their purchases. Businesses that have many years of relationship with their suppliers could place their orders both in the country and abroad and make payments online; the goods would be delivered to them at the time agreed with the suppliers. This signifies that the use of POS and other non-cash payments provides safer ways of making payments to suppliers/sellers. It is therefore remarkable that Nigerians prefer e-payments to cash payments (Oyewole et al., 2013). In addition, it is not uncommon to find disagreements between entrepreneurs and their employees over cash shortages, which leads to sacking many employees. Some of the cases were taken to court and those found guilty were imprisoned. This finding is in line with the findings of the previous studies like Achor and Robert (2013) and Okoye and Ezejiofor (2013), who believe that non-cash payments minimize the robbery of cash and corrupt practices and other related offenses.

Another form of risk associated with cash is fire outbreaks. Some international and regional markets in Kano state like Sabon Gari Market, Kurmi Market and Farm Center (GSM) Market experienced fire accidents, which led to the collapse of many businesses. For example, in Sabon Gari Market, a fire outbreak destroyed at least 6,000 shops (including makeshift stall) within 12 hours, and many traders not only lost their goods but also cash (Adeyemi, 2016). In another report, a fire accident burnt down about $75 \%$ of the market, destroying 3,800 shops containing goods and cash worth 2 trillion (Nigerian currency) (Daily Trust, 2016). Also, the management of Singa Market (another popular one in the state) revealed that over 200 shops (Ikeke, 2016) and 1,200 makeshift stalls were lost to the fire and the total value of the goods and cash lost was more than $\# 3$ billion (Muhammad, 2016). According to the fire service boss, between January 2015 and March 2016, the total value of the wealth lost to fire accidents in various markets in Nigeria was about $\$ 5.30$ trillion (Omokhunu, 2016). Moreover, it has been established that those that suffer most were the ones that substantially kept cash in their shops and offices. Hence, the emir of Kano State (the former governor of the $\mathrm{CBN}$ ) advised the traders to stop keeping their monies in their shops and to adopt Islamic insurance (Takaful) with the view to recovering the losses suffered as a result of the fire outbreak and other accidents (Daily Trust, 2016).

Based on the above, it is understandable that the financial inclusion of the business could serve as a powerful tool for reducing risks that are related to cash.

\subsection{Enhancing business zakāh for poverty alleviation}

The participants in the interviews were asked whether financial inclusion could contribute toward enhancing business zakāh to eradicate poverty. The interviewees $(n=6)$ strongly believe that financial inclusion is likely to play a vital role in the improvement of business $z a k \bar{a} h$. The collected responses are as follows: 
Zakāh could easily be calculated since the records for zakatable assets are kept [. . . it is believed to be a powerful instrument for eradicating poverty [...]. (A1)

[...] it makes it easy to determine the value of assets subject to $z a k a \bar{h}$ because of complete records for the assets [...]. Zakāh is considered to be very useful in reducing poverty to the barest minimum in Islamic society. (A2)

$[\ldots]$ it tends to increase the $z a k \bar{a} h$ payable by the business since there is control over cash, inventory and receivables. (A3)

[...] the records of zakâtable assets of the businesses that are financially included are more complete than those that are not [...] which implies that they are likely going to pay more zakāh. (A4)

As a result of recordkeeping improvement, the financially included are expected to pay more zakāh than those that are financially excluded [...] this could greatly contribute to maximizing zakāh for various poverty alleviation programs. (A5)

[...] the use barcode machine and POS could enable the business to ascertain the balances of the inventories and cash balances at banks respectively which make it easier and convenient to calculate the business $z a k \bar{a} h$ for poverty alleviation [...]. (A6)

The general finding from the above responses show that financial inclusion is an instrument for poverty alleviation, which is in line with the assertions of Mirakhor and Iqbal (2012) and Ocampos (2015). In specific terms, since the financial inclusion of the business enhances its recordkeeping, there is the likelihood of having complete records for zakatable assets by the business. This implies that the amount to pay by the business as zaka h would be maximized to eradicate poverty in Islamic society. Therefore, the higher the amount of business zaka h collected, the higher the chance of alleviating poverty. Zakāh has been proved to be a strong instrument for poverty alleviation in the Muslim world (Mirakhor and Iqbal, 2012; Dixit and Ghosh, 2013; Sharma and Kukreja, 2013; Ismail Abdel Mohsin, 2013; Nadzri et al., 2012; Raimi et al., 2014; Shirazi, 2014; Hoque, 2015; Ocampos, 2015; Zulkhibri, 2016).

Recently, a report released by the Brookings Institution disclosed that at the end of May 2018 , about 87 million Nigerians were living in extreme poverty and six persons became poor every one minute (Vanguard, 2018). Hence, it is time to use zakāh efficiently and effectively for poverty alleviation in Nigeria, because Muslims are the majority there.

\subsection{Sales improvement and business growth}

The maximization of sales revenue and the growth of the business are among its major objectives, more especially in a competitive environment. All the interviewees $(n=6)$ agreed that financial inclusion could lead to sales improvement and business growth. The following are the excerpts of their opinions:

Sales of these businesses grow at a faster rate because mostly their prices are cheaper than the other traders. This enables them to periodically open more branches, not only in the state but in other states of Nigeria. Sometimes other traders that run out of stock do purchase the goods from these businesses (financially included). (A1)

Businesses that are financially included are easy to be located on their corporate addresses [...]. They operate like corporate bodies (even if they are not registered as companies) [...]. This enables them to attract corporate customers that purchase goods in large quantities usually more than the individual customers [...] because they issue them with documents for recordkeeping such as receipts, invoices, etc. These documents are needed for bookkeeping purposes by corporate customers. In other words, government and big companies prefer to transact with these businesses (financially included) that look like companies even if they are not registered as legal entities. (A2)

[...] customers that are out of cash could use their ATM cards to purchase what they want. There are many instances whereby the customers see some products that they want but they could not because

The business financial inclusion benefits

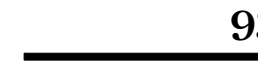


IES

28,1

94

they have no cash. In this case, the customers could use their cards to make the purchase whenever they have no cash to pay for what they intend to buy. (A3)

[...] sales could be improved because the business provides alternative and convenient means of making payment for the purchases [...]. Customers are now afraid of carrying cash to the market. They prefer to use POS and ATM to make payments. This contributes a lot towards improving the sales values and opening more branches of the business. (A4)

Most of the businesses that are financially included have standard prices compared to the others. Consequently, they attract more customers [...] grow and expand faster than those that are financially excluded. (A5)

[...] sales are always improved and the businesses grow faster than those that are not financially included [...] new branches are not only opened in the state but also in other states [...]. (A6)

It has also been established through the observation that the businesses that use POS as an alternative means of making payment attract more customers than those that do not. One good thing for the business is that the price of each product is marked on it. Hence, once a customer picks the product, there is no bargain. More customers are attended by cashiers/sales attendants within a short period. These businesses comparatively charge low selling prices and ensure their products are qualitative and standard as well. Another factor that greatly contributes to their sales is that they hardly run out of inventories because the barcode machine could be used to set minimum inventory, maximum inventory and reorder levels. Consequently, the businesses do not only retain their existing customers but also attract new ones.

\subsection{Supports from government and other development organizations}

There are many programs initiated by Nigerian state and federal governments, government agencies, NGOs, International Donors (such as World Bank, UNESCO, DFID, etc.) to assist micro, small and medium enterprises (MSMEs) toward the provision of employment opportunities, poverty alleviation and economic growth and development at large. Hence, the respondents were asked on the role played by financial inclusion toward getting support from both government and other development organizations. The majority $(n=5)$ are of the view that financial inclusion enables businesses to have access to the supports. The following are the views of the respondents:

Businesses that are financially included have many chances of getting assistance from the government and its agencies and other development organizations [...] (A1)

Financially included businesses are likely to have easy access to credit facilities and grants from various sources such as government, banks and other organizations for development. These bodies do not normally give cash to the beneficiaries; rather through banks [. . .], they have access to the accounts of the businesses for monitoring purposes. In some cases, bank account balances could serve as collateral securities for accessing the loans. (A2)

[...] government and other development organizations usually prefer to transact and deal with the businesses that are financially included. These businesses also stand to have the chance of getting support and assistance from the government and other organizations in form of grants or loans as a result of accidents and other calamities such as fire accidents (which is the most common accident that occurs in the Nigerian markets). (A4)

[... . they are considered first when it comes to getting support and assistance from the government and other development agencies. This is because they are likely to provide more reliable and adequate information about their operations, assets and liabilities. (A5)

Businesses that are financially included find it easy and convenient in any relationship with the government agencies and other development organizations as they look like corporate entities [...] 
they can easily get tax clearance certificate, clearance from custom for the importation of inventories [...]. (A6)

Similarly in Nigeria, it is very common to find that one of the essential requirements for benefiting from most of the government or any development organization programs is that the beneficiary (whether a business or an individual) must have a bank account. Perhaps, this is a major reason why a lot of Nigerians open accounts.

\subsection{The provision of employment opportunities}

It is believed that the government alone could not provide full employment to the people. Therefore, in both developing and developed economies, the private sector provides the most employment opportunities. Here, the respondents were asked to mention their views on whether the financial inclusion of the business could lead to the provision of employment opportunities. All interviewees $(n=6)$ strongly believe that the financial inclusion of the business contributes greatly to the provision of employment opportunities. The excerpts of their responses are as follows:

Financially included businesses employ sales representatives, cashiers, securities, etc. [...]. Therefore, they provide more employment than those that do not adopt the use of the POS terminal and the barcode machine. (A1)

[... ] they provide employment opportunities to the populace if compared to those that are financially excluded. (A2)

$[\ldots]$ as a result of sales improvement and business growth, more employment opportunities would be provided to different types of employees. (A3)

$[\ldots]$ businesses that are financially included provide more employment opportunities than the others. (A4)

[...] they comparatively provide employment opportunities more than those that do not adopt the policy of the financial inclusion [. . . ] some traders have employees who solely assist their customers in making online payments to them (the businesses). Thus, they provide more employment opportunities to the public such as cleaners, securities, agents, cashiers, sales representatives, etc. Some of them are graduates. (A5)

They provide employment opportunities to both skilled labor and unskilled labor more than those that do not adopt the policy of financial inclusion. It is not uncommon to find many businesses that have the capacity to employ at least 15 employees but employ not more than four [... . However, most of those that are financially included employ cleaners, securities, cashiers, counter attendants, sales attendants, accountants, legal practitioners, etc. (A6)

Similarly, the observation results reveal that firms that are financially included are far ahead of those that do not comply with the financial inclusion policy in terms of the provision of employment opportunities to the teeming population. It has been found in the visited shops and stores that people were employed to carry out different responsibilities, such as that of security, sales attendants, drivers, cleaners, cashiers and accounts. This is in line with the finding of Osikena and Uğur (2016), who explored how advancement in financial inclusion services assists in improving competition and the integration of economic sectors, which have all the potentials to drive employment growth across Africa. Sykes et al. (2016) also believe that access to financial services by youth could play a direct role to support the transition to the provision of employment opportunities provided that their ability to use the services is strengthened.

\subsection{Corporate social responsibility}

Finally, the respondents were asked to mention the benefits of financial inclusion other than the ones mentioned above. The majority $(n=4)$ agreed that the financially included
The business financial inclusion benefits 
IES

28,1

96

businesses carry out social responsibilities in one form or the other. They expressed the following responses:

[...] as a result of their growth and development, they discharge various corporate social responsibilities for the welfare of members of society. (A2)

They earn profit and as such, they have the chance to discharge Corporate Social Responsibility (CSR) for the benefits of the members of the society. (A2)

They have concerns for discharging CSR mostly for the welfare of the community in which they are located [. . .] which make them be recognized and respected by members of the community. They can do so because they earned higher profits [...]. (A3)

They contribute tremendously towards the development of the society inform of philanthropic activities such as scholarships, donations to securities agencies, payment for patients' medical services and outstanding bills, donations to the orphanage [... . . (A6).

It has also been observed that the studied businesses perform various religious activities in the form of donations to Islamic schools and mosques and sponsoring various religious programs on radio and television, more especially during the month of Ramadhan (fasting). In fact, financial inclusion is considered to be among the major factors that enhance the profitability of businesses. As earlier mentioned, the review of 76 empirical studies by Ali et al. (2017) found that higher profits stimulate businesses to spend and disclose huge amounts of CSR expenditure in their annual reports and accounts.

\section{Conclusion}

Financial inclusion is a central point to both Islamic and non-Islamic states as well as developed and developing countries. The objective of this paper is to explore the benefits of business financial inclusion for wealth maximization and poverty alleviation in Nigeria. This study utilized primary data by conducting interviews with experts comprising professional accountants/consultants and experienced traders. Also, observations were made in some selected stores and shops that were believed to be financially included. The study reveals the benefits of business financial inclusion to include recordkeeping improvement, the reduction of the risks of bad debts, the reduction of the risks associated with cash, enhancement business $z a k \bar{a} h$ for poverty alleviation, sales improvement and business growth, getting support from government and other development organizations and the provision of employment opportunities. Other benefits are carrying out religious and other philanthropic activities which greatly contribute to the welfare of the ummah.

\section{Note}

1. The Western Sudan is a historic region in the northern part of West Africa, not simply the presentday country Sudan.

\section{References}

Achor, P.N. and Robert, A. (2013), "Shifting policy paradigm from cash-based economy to cashless economy: the Nigeria experience", Afro Asian Journal of Social Sciences, Vol. 4 No. 4, pp. 1-16.

Adeyemi, K. (2016), "Fresh fire hits Kano market", The Nation, Vol. 27, March, available at: http:// thenationonlineng.net/fresh-fire-hits-kano-market/ (accessed 10 October 2018).

Ali, A.E. (2015), "Islamic microfinance: moving beyond financial inclusion", European Scientific Journal, Vol. 11 No. 10, pp. 297-310. 
Ali, W., Frynas, J.G. and Mahmood, Z. (2017), "Determinants of corporate social responsibility (CSR) disclosure in developed and developing countries: a literature review", Corporate Social Responsibility and Environmental Management, pp. 1-22, doi: 10.1002/csr.1410.

Andrianaivo, M. and Kpodar, K. (2012), "Mobile phones, financial inclusion and growth", Review of Economics and Institutions, Vol. 3 No. 2, pp. 1-30.

Bakar, A.F. and Yusof, M.A.M. (2016), "Managing CSR initiatives from the islamic perspective: the case of bank islam Malaysia Berhad (BIMB)", Jurnal Pengurusan, Vol. 46, pp. 67-76.

Bayero, M.A. (2015), "Effects of cashless economy policy on financial inclusion in Nigeria: an exploratory study", Procedia - Social and Behavioral Sciences, pp. 49-56.

Beg, S. and Mullick, N.H. (2016), "Increasing financial inclusion through Islamic banking in India", International Journal of Business Management and Research (IJBMR), Vol. 6 No. 1, pp. 27-34.

Brekke, T. (2018), "Halal money: financial inclusion and demand for Islamic banking in Norway", Research and Politics, Vol. 5 No. 1, pp. 1-7.

Central Bank of Nigeria (CBN) (2019), Financial Inclusion Newsletter, (2nd Quarterly), Vol.4 No. 2, available at: https://www.cbn.gov.ng Out)CCD $\rangle$ 22019FinancialInclusionNewsl (accessed 3 December 2019).

Central Bank of Nigeria (CBN) (n.d.), "Cash-less Nigeria”, available at: https://www.cbn.gov.ng/ cashless/ (accessed 2 December 20191).

Daily Trust (2016), "Kano market fire: we lost N2tr -sarkin kasuwa”, Daily Trust, Vol. 27, March, available at: https://www.dailytrust.com.ng (accessed 10 November 2018).

Dan-Asabe, A.U. (1987), "Comparative biographies of selected leaders of the Commercial establishment", Thesis Submitted to Bayero University, Kano, in partial fulfilment of the requirements for the Degree of Master of Arts, Department of History, Faculty of Arts and Islamic studies.

Demirguc-Kunt, A., Klapper, L. and Randall, D. (2014), "Islamic finance and financial inclusion: measuring use of and demand for formal financial services among Muslim Adults", Review of Middle East Economic Finanace, Vol. 10 No. 2, pp. 177-218.

Dixit, R. and Ghosh, M. (2013), "Financial inclusion for inclusive growth of India - a study of Indian states", International Journal of Business Management and Research (IJBMR), Vol. 3 No. 1, pp. 147-156.

Enhancing Financial Innovation and Access (EFInA) (2018), Access to Financial Services in Nigeria 2018 Survey, available at: https://www.efina.org.ng/wp-content)uploads)2019/019 (accessed 3 December 2019).

Eldabi, T., Irani, Z., Paul, R.J. and Love, P.T.D. (2002), "Quantitative and qualitative decision-making methods in simulation modeling", Management Decisions, Vol. 40 No. 1, pp. 64-73.

Er, B. and Mutlu, M. (2017), "Financial inclusion and Islamic finance: a survey of Islamic financial literacy index", International Journal of Islamic Economics and Finance Studies, Vol. 3 No. 2, pp. 33-52.

Gentles, S.J., Charles, C., Ploeg, J. and McKibbon, K. (2015), "Sampling in qualitative research: insights from an overview of the methods literature", The Qualitative Report, Vol. 20 No. 11, pp. 1772-1789.

Hoque, N., Khan, M.A. and Mohammad, K.D. (2015), "Poverty alleviation by $z a k a \bar{h}$ in a transitional economy: a small business entrepreneurial framework”, Journal of Global Entrepreneurship Research, Vol. 5 No. 7, pp. 1-20.

Horton, J., Macve, R. and Struyven, G. (2004), "Qualitative research: experiences in using semi structured interviews", in Humphrey, C. and Lee, B. (Eds), The Real Life Guide to Accounting Research: A Behind-The-Scenes View of Using Qualitative Research Methods, Elsevier, London, pp. 339-357, doi: 10.1016/B978-008043972-3/50022-0.

Ibrahim, A.M. (2015), "Evolutionary trend, spatial distribution of, and issues associated with markets in Kano metropolis", International Journal of Physical and Human Geography, Vol. 3 No. 2, pp. 9-24.

Ikeke, N. (2016), "Early morning fire guts popular Singa market in Kano", available at: https://www. naija.ng/734928-just-popular-kano-market-destroyed-fire-guts-kano-singa-market.html\#734928 (accessed 5 November 2018).

The business financial inclusion benefits 
IES

28,1

98

Ismail Abdel Mohsin, M. (2013), "Financing through cash-waqf: a revitalization to finance different needs", International Journal of Islamic and Middle Eastern Finance and Management, Vol. 6 No. 4, pp. 304-321, doi: 10.1108/IMEFM-08-2013-0094.

Kelkar, V. (2009), "Financial inclusion for inclusive growth", ASCI Journal of Management, Vol. 39 No. 1, pp. 55-68.

Marshall, B., Cardon, P., Poddar, A. and Fontenot, R. (2013), "Does sample size matter in qualitative research?: a review of qualitative interviews in IS research", Journal of Computer Information Systems, Vol. 54 No. 1, pp. 11-22.

McDonell, G. (1964), "The dynamics of geographic change: the case of Kano", Annals of the Association of American Geographers, Vol. 54 No. 3, pp. 355-371.

Mirakhor, A. and Iqbal, Z. (2012), "Financial inclusion: Islamic finance perspective", Journal of Islamic Business and Management, Vol. 2 No. 1, pp. 35-64.

Mohieldin, M., Iqbal, Z., Rostom, A. and Fu, X. (2012), "The role of Islamic finance in enhancing financial inclusion in Organization of Islamic Cooperation (OIC) countries", Islamic Economic Studies, Vol. 20 No. 2, pp. 55-120.

Muhammad, A. (2016), "1,400 shops burnt in Kano market fire", Vanguard, Vol. 19, February, available at: https://www.vanguardngr.com/2016/02/1400-shops-burnt-in-kano-market (accessed 12 January 2018).

Muktar, M. (2013), "Empirical examination of the factors that lead to the emergence of entrepreneurs in Kano state, Nigeria”, International Journal of Humanities and Social Science Invention, Vol. 2 No. 2, pp. 38-44.

Mustafa, D., Baita, A.J., Adhama, H.D. and Muhammad, S. (2018), "Potential revenue base of zakat institution for poverty alleviation in Kano State, Nigeria", Being a Research Submitted to Islamic Research and Training Institute (IRTI), Jeddah.

Naceur, S.B., Barajas, A. and Massara, A. (2015), “Can islamic banking increase financial inclusion?”, IMF Working Paper WP/15/31, available at: https://www.imf.org)Publications)Issues)2016/12/ 31>Can-Islamic-Ba (accessed 18 December 2018).

Nadzri, F.A.A., AbdRahman, R. and Omar, N. (2012), "Zakat and poverty alleviation: roles of zakat institutions in Malaysia", International Journal of Arts and Commerce, Vol. 1 No. 7, pp. 61-72.

Nor, S.M. and Hashim, N.A. (2015), "CSR and sustainability of Islamic banking: the bankers view", Jurnal Pengurusan, Vol. 45, pp. 73-81.

Ocampos, L. (2015), "Can Islamic banking increase financial inclusion in the Muslim world?", available at: http://blog-montada.imf.org/:iMFdirect (accessed 10 August 2018).

Okoye, P.V.C. and Ezejiofor, R. (2013), "An appraisal of cashless economy policy in development of Nigerian economy", Research Journal of Finance and Accounting, Vol. 4 No. 7, pp. 237-253.

Omokhunu, G. (2016), “600 lives, goods worth N5 trillion lost to market fire, says fire service's boss”, The Nation, available at: http://thenationonlineng.net/600-lives-goods-worth-n5tr-lost-marketfire-says-fire-services-boss/ (accessed 5 November 2018).

Osikena, J. and Uğur, D. (2016), "Enterprising Africa what role can financial inclusion play in driving employment-led growth?”, Foreign Policy Centre (FPC) Report, available at: www.fpc.org.uk (accessed 1 January 2019).

Oyewole, O.S., El-Maude, Gambo, J., Abba, M. and Ezekie, M. (2013), "Electronic payment system and economic growth: a review of transition to cashless economy in Nigeria", International Journal of Scientific Engineering and Technology, Vol. 2 No. 9, pp. 913-918.

Raimi, L., Patel, A. and Adelopo, I. (2014), "Corporate social responsibility, waqf system and zakat system as faith-based model for poverty reduction", World Journal of Entrepreneurship, Management and Sustainable Development, Vol. 10 No. 3, pp. 228-242.

Seman, J.A. (2016), Financial Inclusion: The Role of Financial System and other Determinants, Unpublished doctoral dissertation, University of Salford, Salford, available at: https://www.imf. 
org/en/Publications/WP/Issues/2016/12/31/Can-Islamic-Banking-Increase-Financial-Inclusion42710 (accessed 21 November 2018).

Shaikh, S.A., Ismail, M.A., Shafiai, M.H.M., Ismail, A.G. and Shahimi, S. (2017), "Role of Islamic banking in financial inclusion: prospects and performance”, in Alam, N. and Rizvi, S.A.R. (Eds), Islamic Banking, Palgrave CIBFR Studies in Islamic Finance, pp. 33-49, doi: 10.1007/978-3-31945910-3_3.

Sharma, A. and Kukreja, S. (2013), "An analytical study: relevance of financial inclusion for developing nations", International Journal of Engineering and Science, Vol. 2 No. 6, pp. 15-20.

Shirazi, N.S. (2014), "Integrating zakāt and waqf into the poverty reduction strategy of the IDB member countries", Islamic Economic Studies, Vol. 22 No. 1, pp. 79-108.

Sykes, J., Elder, S., Gurbuzer, Y. and Principi, M. (2016), "Exploring the linkages between youth financial inclusion and job creation: evidence from the ILO school-to-work transition surveys", International Labour Office (ILO) Report, available at : www.ilo.org/publns (accessed 1 January 2019).

Thaker, M.A.M. (2018), "A qualitative inquiry into cash waqf model as a source of financing for micro enterprises”, ISRA International Journal of Islamic Finance, Vol. 10 No. 1, pp. 19-35.

Umar, U.H. (2019a), "A basic comprehensive accounting package for mushārakah: consolidation of Islamic and conventional practices", in Ghazali, E., Mutum, D., Rashid, M. and Ahmed, J. (Eds), Management of Shari'ah Compliant Businesses. Management for Professionals, Springer, Cham, pp. 85-93, doi: 10.1007/978-3-030-10907-3_8.

Umar, U.H. (2019b), "Integrating family waqf into an inheritable going concern business: an instrument for the sustainable welfare of exempted heirs", in Ali, K.M., Hassan, M.K. and Elzahi Saaid Ali, A. (Eds), Revitalization of WAQF for Socio-Economic Development, Palgrave Macmillan, Cham, Vol. II, pp. 67-87, doi: 10.1007/978-3-030-18449-0_4.

Umar, U.H. and Kurawa, J.M. (2019), "Business succession from an Islamic accounting perspective", ISRA International Journal of Islamic Finance, Vol. 11 No. 2, pp. 267-281, doi: 10.1108/IJIF-062018-0059.

Umar, U.H., Ado, M.B. and Ayuba, H. (2019), “Is religion (interest) an impediment to Nigeria's financial inclusion targets by the year 2020? a qualitative inquiry", Qualitative Research in Financial Market. doi: 10.1108/QRFM-01-2019-0010.

Umar, U.H., Kademi, T.S. and Haron, M.H. (2020), "Integrating $w q \bar{a} f$ and business: ensuring business sustainability for the welfare of heirs and non-heir", International Journal of Economics, Management and Accounting, Vol. 28 No. 1, pp. 191-213.

Vanguard (2018), "Nigeria overtakes India as world's poverty capital - report", Vol. 25, June, available at: https://www.vanguardngr.com/2018/06/nigeria-overtakes-india-as-worlds-povertycapital-report/ (accessed 20 November 2018).

Zauro, N.A., Mas'ud, A., Alkali, M.Y. and Abdullahi, N. (2017a), "Enhancing financial inclusion through Islamic income redistribution: the role of zakat, sadaqah, and qard hasan", A paper presented at the 3rd International Conference on Social Science and Law-Africa (ICSSL-Africa), 10-11 May, held at Nile University of Nigeria (NUN), Abuja.

Zauro, N.A., Saad, R.A. and Sawandi, N. (2017b), "Do attitude, religiosity and ethnicity Influence financial inclusion?", A paper presented at the 3rd International Conference on Social Science and Law-Africa (ICSSL-Africa), 10-11 May, held at Nile University of Nigeria (NUN), Abuja.

Zulkhibri, M. (2016), "Financial inclusion, financial inclusion policy and Islamic finance", Macroeconomics and Finance in Emerging Market Economies, pp. 1-18, doi: 10.1080/ 17520843.2016 .1173716$.

\section{Further reading}

Al-Hilali, M.T. and Khan, M.M. (n.d.), Translation of the Meanings of the Noble Qur'anin the English Language, King Fahd Complex for the Printing of the Noble Qur'an, Madinah.

The business financial inclusion benefits 
Khan, M.M. (2009), “Translation of Sahih Bukhari”, available at: https://d1.islamhouse.com/data/en/ih_ books/single/en_Sahih_Al-Bukhari.pdf (accessed 20 May 2017).

Siddiqui, A.H. (2009), "Translation of Sahih Muslim”, available at: https://d1.islamhouse.com/data/en/ ih_books/single/en_Sahih_Muslim.pdf (accessed 20 November 2017).

Umar Habibu Umar can be contacted at: uhumar21@gmail.com

For instructions on how to order reprints of this article, please visit our website: www.emeraldgrouppublishing.com/licensing/reprints.htm Or contact us for further details: permissions@emeraldinsight.com 